\begin{abstract}
Universidade de Brasília
Centro de Excelência em Turismo

Curso de Especialização lato sensu em Qualidade em Alimentos
\end{abstract}

\title{
O Sistema Sous Vide
}

Ana Elisa Aguiar Ramos

BRASÍLIA - DF

JUNHO DE 2004 


\author{
Universidade de Brasília \\ Centro de Excelência em Turismo \\ Curso de Especialização lato sensu em Qualidade em Alimentos
}

\title{
O Sistema Sous Vide
}

\author{
Ana Elisa Aguiar Ramos
}

Monografia apresentada ao Curso de Especialização lato sensu em Qualidade em

Alimentos, Centro de Excelência em Turismo, Universidade de Brasília, como requisito para obtenção do Título de Especialista em Qualidade em Alimentos.

Professor MsC. Luiz Antônio Borgo - Orientador

BRASÍLIA - DF

JUNHO DE 2004 
Ana Elisa Aguiar Ramos

O SISTEMA SOUS VIDE

Comissão Avaliadora

Brasília, DF, junho de 2004 


\section{DEDICATÓRIA}

Aos meus pais, Luiz Carlos Ramos de Lima e Helena Aguiar Ramos, às minhas irmãs, Tarsila Aguiar Ramos e Zildene Aguiar Ramos e aos meus queridos sobrinhos Tainá e Vítor. 


\section{AGRADECIMENTOS}

Agradeço a Deus pela saúde e proteção de todos os dias. Agradeço ao Professor Luiz Antônio Borgo pela colaboração e orientação durante o transcorrer deste estudo. 


\section{RESUMO}

O sistema Sous Vide é uma expressão francesa que significa "a vácuo". Este sistema de cozimento teve sua introdução na França na década de 70 , do século passado, por Bruno Goussault e sua equipe. O cozimento Sous Vide consiste em embalar o produto, que pode ser desde carnes até massas, a vácuo e depois submetêlo a um cozimento lento com temperaturas baixas, temperaturas estas designadas pela característica individual de cada produto. O produto, durante o cozimento, sofre um tratamento térmico comparável às condições da pasteurização, que ocorre pelo choque térmico ao qual o produto é submetido. As temperaturas podem atingir $54^{\circ} \mathrm{C}$ a $72^{\circ} \mathrm{C}$ para o cozimento, e $0^{\circ} \mathrm{C}$ a $2^{\circ} \mathrm{C}$, para o resfriamento. Com estas temperaturas, reduzemse as formas vegetativas de bactérias patogênicas e, considerando que está isento de oxigênio devido a embalagem a vácuo e sob temperaturas de $0^{\circ} \mathrm{C}$ a $3^{\circ} \mathrm{C}$, pode ser conservado por 3 a 4 semanas. O produto, por ser cozido sob vácuo, conserva suas características nutricionais e não perde seus sucos naturais, tornando-se um alimento mais tenro e suculento. Com tantas vantagens, o produto Sous Vide faz um enorme sucesso em caterings, hotéis e restaurantes.

Palavras-chave: sous vide, tratamento térmico, produtos prontos, alimentação institucional. 


\begin{abstract}
The Sous Vide system is a french expression that means "on the vacuum". This baking system had introduction in France in the decade of 70 , of the passed century, for Bruno Goussault and its team. The baking Sous Vide consists of packing the product, that can be since meats until masses, the vacuum and later submitting it a slow baking with low temperatures, temperatures these assigned person for the individual characteristic of each product. The product, during the baking, suffers a comparable thermal treatment to the conditions from the pasteurization that occurs for the thermal shock to which the product is submitted. The temperatures can reach $54^{\circ} \mathrm{C} 72^{\circ} \mathrm{C}$ for the baking, and $0^{\circ} \mathrm{C} 2^{\circ} \mathrm{C}$, for the cooling. With these temperatures, the vegetative forms of pathogenic bacteria e are scrumbled, considering that he is exempt of oxygen due the packing the vacuum and under temperatures of $0^{\circ} \mathrm{C} 3^{\circ} \mathrm{C}$, can be conserved by 3 the 4 weeks. The product, for being cooked under vacuum, conserve its nutritional characteristics and does not lose its natural juices, becoming tender and a more succulent food. With as many advantages, the product Sous Vide makes an enormous success in caterings, hotels and restaurants.
\end{abstract}

Key-words: sous vide, thermal treatment, ready products, institution feeding. 


\section{SUMÁRIO}

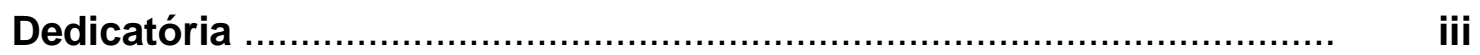

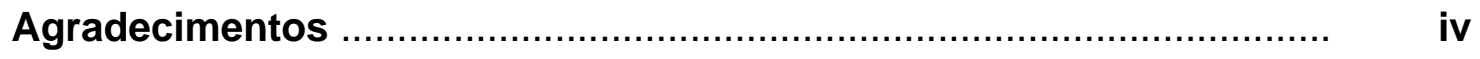

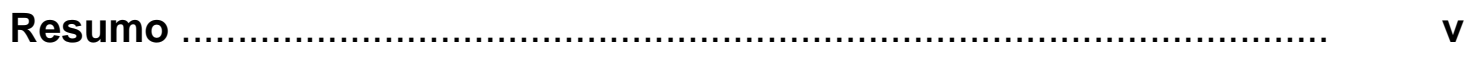

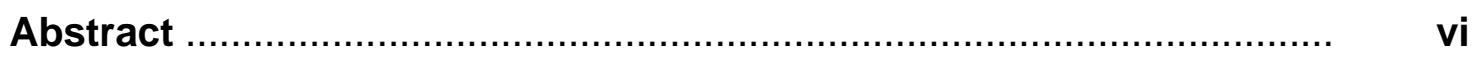

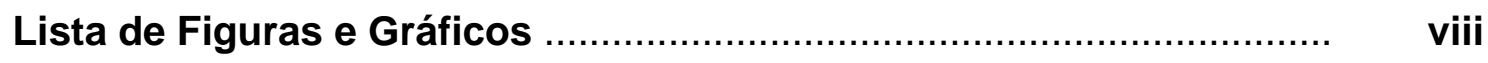

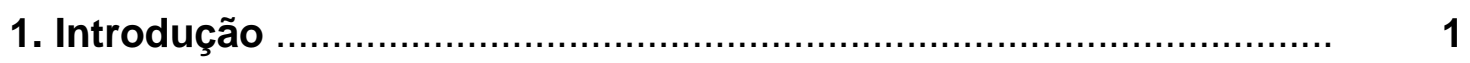

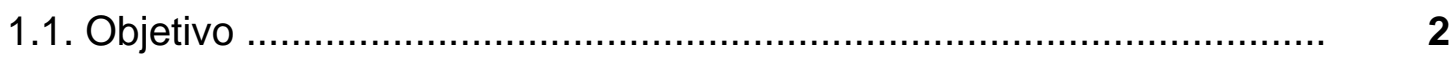

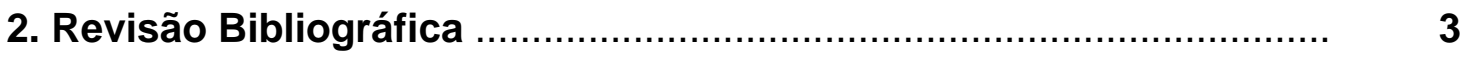

2.1. Princípios da Preservação e conservação de alimentos ................... 3

2.2. Sous Vide ........................................................................... 4

2.2.1. Histórico ............................................................................. 4

2.2.2. Procedimentos Operacionais .............................................. $\quad 6$

2.2.3. Método e características de qualidade .................................... 11

2.2.3.1 Vida útil .................................................................... 13

2.2.3.2 Sensorial ................................................................. 14

2.2.3.3. Microbiologia .................................................... 15

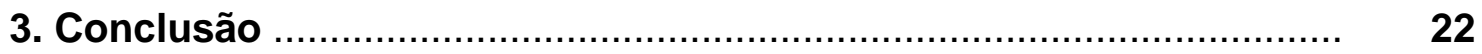

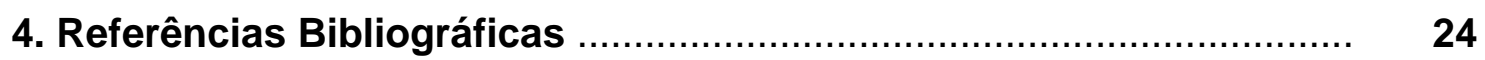




\section{LISTA DE FIGURAS I QUADROS}

Quadro 1 - Fases da produção Sous Vide................................... $\quad 7$

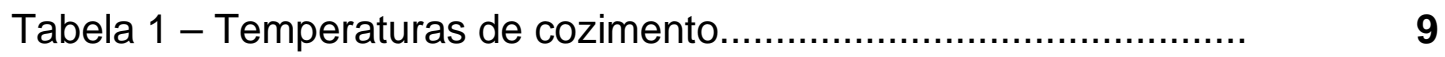

Figura 1 - Fluxograma de um sistema tradicional...................... 12

Figura 2 - Fluxograma de produção Sous Vide.............................. 14 


\section{INTRODUCÃO}

Os últimos cinco anos foram incontestavelmente marcados pelo fenômeno do "cozimento a vácuo" ou do cozimento de um produto no seu último acondicionamento. O cozimento a vácuo ora um retorno à tradição culinária, ora, tratava-se de uma verdadeira revolução tecnológica.

O cozimento a vácuo provocou, um impacto extraordinário na mídia. Trouxe, evidentemente, uma nota harmônica às variedades gustativas da cozinha. Os produtos cozidos a vácuo adquirem uma força gustativa que não lhes é habitual e que revelava apenas o antepassado desta técnica de cozimento em folha de papel de alumínio. A culinária, na sua diversidade, não está reduzida certamente a esta única técnica e não seria desejável. É preciso encontrar o ponto certo para medir o que o cozimento a vácuo pode trazer ao conjunto das atividades de transformação e de distribuição dos produtos alimentares.

A história do Sous Vide começou na França, no início dos anos setenta. O Chef Georges Pralus descobriu que colocando o alimento em uma bolsa plástica a vácuo e cozinhando-o lentamente em temperatura precisamente determinada poderia obter maior rendimento e um sabor infinitamente superior. Na metade da década de 80, quando a alta gastronomia se tornou famosa nos serviços de bordo nos trens na França, Chefs e caterers mudaram seu foco para a qualidade. Foi quando Bruno Goussault, também conhecido como um dos fundadores do Sous Vide, refinou os parâmetros de cozimento e a relação entre tempo, temperatura e validade dos 
alimentos. Desde então, o Sous Vide tornou-se um método de cozimento celebrado pelos melhores Chefs de cozinha da Europa, os quais empregaram a técnica de cozimento Sous Vide em seus notáveis restaurantes (CREA, 2000).

A tecnologia Sous Vide é, antes de tudo, um método de cozimento extremamente delicado e lento, capaz de enaltecer a qualidade da matéria-prima processada. O sabor original dos alimentos, seus nutrientes e sucos naturais são preservados no cozimento a vácuo, o que resulta em uma qualidade e padronização virtualmente impossível de se imitar pelos métodos tradicionais. Esta técnica é capaz de eliminar todos os problemas de cor, sabor e textura dos alimentos, geralmente associados à comida congelada. Além de sabor, cor e textura diferenciados, os produtos cozidos no sistema Sous Vide oferecem segurança, por sua tecnologia de cozimento, pois elimina os riscos de contaminação dos alimentos por bactérias, uma vez que os alimentos são pasteurizados totalmente na embalagem final (CREA, 2000).

\subsection{Objetivo}

Identificar os parâmetros tecnológicos e de controle de qualidade para o sistema Sous Vide 


\section{REVISÃO BIBLIOGRÁFICA}

\subsection{Princípios da Preservação e conservação de alimentos}

Desde os primórdios, a preocupação com a qualidade dos alimentos é grande, quando se nota a constante procura por alimentos sensorialmente mais adequados, entre outros requisitos.

Durante muitos séculos, o homem tem lutado com o problema da conservação de alimentos. Os antigos egípcios e romanos tinham conhecimento dos efeitos preservativos do sal, da dessecação e da defumação. Sugeriu-se que a primeira salga foi realizada enterrando-se o alimento na praia, onde a água do mar realizava a cura. Os índios americanos colocavam tiras de bisão e de veado no alto de uma tenda ou sobre uma fogueira, onde a conservação era devida a dessecação ou à defumação, respectivamente. O bacalhau seco e salgado era um alimento comum entre os colonos americanos. Os alimentos perecíveis eram guardados em cavernas e fontes, onde a baixa temperatura prolongava a conservação desejada (TUDO, 2003).

Quando se pôde unir a qualidade do alimento ao sabor, aparência, valores nutricionais preservados e à conservação, pode-se imaginar o sucesso que o sistema Sous Vide teve nas indústrias alimentícias, catering aéreos e, principalmente, para seus consumidores diretos. 


\subsection{Sous Vide}

\subsubsection{Histórico}

Sous Vide é uma expressão francesa que significa a vácuo. Na Dinamarca, o método Sous Vide também é conhecido como cozimento a vácuo. Os produtos alimentícios Sous Vide são submetidos a tratamento térmico especial em bolsas plásticas. O produto pode ser inserido nestas bolsas ainda cru, ou apenas pré-cozido. $\mathrm{O}$ tratamento térmico atinge temperaturas entre $60^{\circ} \mathrm{C}$ e $90^{\circ} \mathrm{C}$. Depois deste tratamento os produtos são resfriados e estocados em câmaras frias (KOLVA, 2003).

Empresas também optam pelo congelamento após o produto ser resfriado e, assim, é estocado em câmaras a $-25^{\circ} \mathrm{C}$, podendo atingir 18 meses de validade. $\mathrm{O}$ método Sous Vide é um desenvolvimento adicional do método convencional de cozimento. Entretanto, a vida de prateleira dos produtos é mais longa do que quando comparados com os produtos conservados pelo método tradicional, visto que o alimento não pode ser recontaminado pelas bactérias após o tratamento térmico realizado.

A introdução na França do procedimento "cozimento a vácuo" está ligada ao progresso das técnicas de conservação a vácuo dos produtos frescos, que data do começo da década de 70 , do século passado, e se concretizou de maneira diferencial em dois setores industriais. Nos produtos salgados, o procedimento foi aplicado para cozer presuntos no seu acondicionamento definitivo. Esta técnica conheceu um rápido 
sucesso, seja no acondicionamento rígido (procedimento Gatineau) seja no acondicionamento mole (procedimento Soplaril). Assim, 20 anos mais tarde, a maioria dos produtos salgados utiliza esta técnica (GOUSAULT, 1993).

Na culinária, os desenvolvimentos foram muitos mais lentos. Foi preciso esperar 1978 para que, sob o impulso de Grace Cryovac, novas tentativas se realizassem. Tratava-se, no momento, de valorizar a maciez de certos músculos do boi para um cozimento longo a baixa temperatura. A colocação a vácuo dos músculos permitia utilizar o cozimento por imersão em banhos de água controlados por termostato. As exigências regulamentares de cozimento completo $\mathrm{a}+65^{\circ} \mathrm{C}$ e a validade limitada $\mathrm{a}$ seis dias não permitiram desenvolver estas pesquisas em nível industrial. No mesmo período, a Sociedade Fleury Michon desenvolvia uma gama de pratos cozidos acondicionados a vácuo e submetidos à pasteurização. Enfim, em 1980, sobre o plano artesanal, Georges Pralus elaborava um método de trabalho em culinária, utilizando o vácuo. Este método foi rapidamente adotado por profissionais de grande talento, o que Ihe deu renome e iniciou os desenvolvimentos que se conhecem hoje (CREA, 2000).

O mercado dos pratos preparados em atmosfera modificada e dos produtos cozidos a vácuo se desenvolveu progressivamente no universo dos produtos frescos. Seu desenvolvimento recente ainda continua muito ligado à noção de cozimento ou de pasteurização no acondicionamento final e à emergência do cozimento chamado "a vácuo", como também à qualidade dos produtos oriundos destas novas técnicas. Sobre o plano tecnológico, trata-se de um universo muito grande onde se encontram, lado a lado, noções muito diversas e por vezes contraditórias: pasteurização e cozimento à 
temperatura correta; pratos preparados e bases culinárias; a vácuo e atmosfera modificada; conjunto, cozinha em kit e pratos mijotés (pratos cozidos em fogo brando)(GOUSAULT, 1993).

\subsubsection{Procedimentos operacionais}

Geralmente, aditivos não são usados na indústria do Sous Vide. O tratamento térmico é um processo relativamente delicado e equivale à pasteurização. Às vezes, o termo Sous Vide também é utilizado para produtos esterilizados, produtos que contenham aditivos e alimentos congelados. Os benefícios para o produto são vários, dentre eles estão: qualidade em sua consistência, mais macio, suculento e alto valor nutricional, valor este preservado durante o cozimento; validade de $3-4$ semanas a $3^{\circ} \mathrm{C}$; cor ressaltada; sem uso de aditivos. E os benefícios para a produção são: minimização do desperdício, equipe de funcionários reduzida, serviço mais rápido e planejamento de produção com mais flexibilidade (KOLVA, 2003).

O estudo realizado por ARMSTRONG (2003) analisou, com técnicas rigorosas, a aceitação sensorial dos produtos Sous Vide, durante o armazenamento, pelos consumidores. Os resultados indicaram que a aceitação dos produtos à base de carne continuou mesmo após armazenamento por 40 dias e os produtos à base de vegetais por 20 dias, após armazenamento. Estes valores estão além do prazo de vida útil atual estipulado pela indústria do Sous Vide e são resultado do desenvolvimento eficaz da receita e do tratamento térmico durante o processamento e armazenamento destes produtos. 
Um fluxograma de produção, de uma empresa localizada no Distrito Federal, a qual trabalha com este sistema de cozimento, está apresentado no quadro 1. Os produtos são embalados a vácuo e em seguida são levados ao cozimento em um moderno equipamento. Durante este processo de cozimento, uma sonda inserida no centro geométrico do alimento registra todas as temperaturas atingidas durante 0 cozimento e resfriamento. Estas temperaturas ficam registras em relatório fornecido pelo equipamento e a equipe responsável pelo controle de qualidade confere cada produto que é submetido a este sistema de cozimento garantindo, assim, que o produto seja cozido e resfriado dentro dos padrões exigidos.

\section{Quadro 1 - Fases da produção Sous Vide}

1. Pré-cozimento: os produtos podem ser embalados ainda cru, contudo, geralmente, as indústrias pré-cozinham os produtos antes de serem embalados a fim de melhorar a apresentação final do produto. Os produtos podem ser grelhados, dourados ou assados;

2. Embalagem a vácuo: os produtos são embalados em bolsas plásticas e submetidas ao vácuo. Os produtos embalados a vácuo têm sua vida de prateleira prolongada, porque o oxigênio que é retirado da embalagem, minimizando, assim, o crescimento de alguns microorganismos, tais como a Samonella e Listeria monocytogenes;

3. Cozimento/Resfriamento: Nesta fase é onde realmente acontece o Sous Vide; os produtos são levados ao cozimento, onde as temperaturas vão depender do tipo do produto. Logo após o cozimento, os produtos são resfriados.

4. Congelamento: Os produtos são congelados em túnel com corrente de ar à temperatura de $45^{\circ} \mathrm{C}$ (negativos).

Os produtos podem sofrer um pré-tratamento térmico de descoramento ou de marcação (por exemplo; marcas de grelha) mais ou menos acentuado, tendo por objetivo homogeneizar o tratamento térmico final e valorizar certos gostos ou aspectos. 
Para cozer um produto na água ou no vapor, é preciso protegê-lo e, principalmente, não introduzir nenhuma camada de ar entre o produto e o envelope de proteção. Assim, o acondicionamento a vácuo em plástico mole é o mais adaptado para o controle da temperatura correta. Esta técnica melhora a qualidade do produto porque os aromas não podem se dispersar e o produto é protegido das oxidações.

A técnica Sous Vide precisa que pratos cozidos não sejam mais trabalhados, e sim que sejam bases culinárias, ou seja, pratos que serão em seguida reunidos na produção ou utilizadas de acordo com as necessidades e tendências do mercado.

As temperaturas e os tempos abaixo mencionados na tabela 1 são orientações encontradas na literatura, para carne e podem ser alteradas dependendo da qualidade do produto, quantidades de salmoura e validade desejada. 
Tabela 1 - Temperaturas de Cozimento

\begin{tabular}{|l|c|c|}
\hline Produto & Temperatura $\left({ }^{\circ} \mathrm{C}\right)$ & Tempo (minutos) \\
\hline Frango & 75 & 15 \\
\hline Pato & 80 & 20 \\
\hline Peixe & 75 & 10 \\
\hline Cordeiro & 75 & 20 \\
\hline Porco & $70-80$ & 15 \\
\hline Peru & 75 & 10 \\
\hline Vitela ou filé de vitela & 66 & 150 \\
\hline Roast beef & 88 & 19 \\
\hline Filé & 59 & \\
\hline (fonte: KOLVA, 2003) & & \\
\hline
\end{tabular}

O cozimento tem por função valorizar as características organolépticas dos produtos e garantir sua conservação posterior. A valorização das características organolépticas resulta da preservação, da modificação ou mesmo do desaparecimento de certas propriedades funcionais dos componentes bioquímicos dos produtos. O calor é um dos fatores preponderantes em todas estas reações e transformações e o domínio do binômio tempo/temperatura para cada produto, de acordo com a natureza do resultado a ser obtido, é determinante (CREA, 2000).

O cozimento tem uma função dupla. Trata-se, antes de tudo, de valorizar as características organolépticas. Em seguida, é preciso garantir a salubridade e a 
conservação dos produtos. As características organolépticas de uma carne - cor, suco e maciez - são modificadas de uma maneira mais ou menos duradoura pelo nível térmico do cozimento. É possível, atualmente, definir precisamente a temperatura de passagem do universo do cru sangrento para o universo do cozido. $\mathrm{A} 62^{\circ} \mathrm{C}$ a albumina contida no sarcoplasma da fibra muscular é desnaturada: ela coagula e forma uma membrana branca entre a mioglobina, responsável pela cor vermelha da carne. Esta membrana modifica a percepção da cor sem mudar o pigmento responsável. Assim, esta percepção pode ser reversível enquanto a temperatura for inferior ao patamar de desnaturação da globina. Quando este patamar é ultrapassado, a cor se torna bem mais estável. Da mesma maneira, a $68^{\circ} \mathrm{C}$, a actina, a miosina e os complexos que elas originam, como também outras proteínas miofibrilares, são desnaturadas. Esta desnaturação provoca, em particular, a perda do poder de retenção de água da carne. Esta passa do universo suculento ao universo do seco (GOUSSAULT, 1996).

A carne suculenta depende do poder de retenção da água das proteínas miofibrilares. Quando do cozimento dos presuntos, os produtos que foram salgados nunca ultrapassam $68^{\circ} \mathrm{C}$, com o objetivo de obter um bom rendimento. Isto é baseando em dados teóricos sobre a desnaturação nesta temperatura das proteínas miofibrilares, que perdem então o poder de reter a água.

O amolecimento de uma carne obedece a uma outra lógica. Sua rigidez está ligada ao seu nível de maturação. Ele é composto de fibras de colágeno e de elastina cuja desnaturação não é suficiente para amolecer o músculo; ao contrário, o calor provoca geralmente uma retração de colágeno, o que leva a um endurecimento do 
músculo. Para obter a maciez desejada, é indispensável hidrolisar e solubilizar os elementos que constituem este tecido conjuntivo e para isso é preciso trabalhar com o tempo. Assim, a valorização das características organolépticas de um pedaço de carne ou de um músculo depende da escolha do binômio tempo-temperatura de cozimento. A definição do binômio tempo-temperatura de cozimento do peixe, que obedece aproximadamente as mesmas regras da carne, caso a rigidez não existisse, poderia ser mais simples, se este produto não se tornasse rapidamente a sede de uma intensa proteólise difícil de parar ou de diminuir (GOUSSAULT, 1996).

Assim, fica claro que cada produto possui um tempo/temperatura de cozimento capaz de valorizar suas características organolépticas de acordo com a natureza da receita. Este binômio difere enormemente entre os diversos elementos que entram na composição de um prato cozido (CREA, 2000).

\subsubsection{Métodos e as características de qualidade}

A técnica Sous Vide interessa hoje aos industriais à medida que um número de bases culinárias é comum a um grande número de receitas. É sempre mais produtivo para uma cozinha preparar 12 bases que darão origem a mais de 200 receitas do que elaborar cada uma destas 200 receitas (CREA, 2000).

Os métodos de produção de alimentos dentro das indústrias de hotel e catering evoluíram em um longo período. O conceito da culinária tradicional mudou o pensamento de gerentes e chefs em todos os setores de hospitais, caterings, hotéis e 
restaurantes. As cozinhas foram equipadas para atender à demanda dos cardápios, centralizando, assim, o sistema de produção da tecnologia avançada com a entrada do sistema Sous Vide.

Em catering tradicional, o alimento é preparado e cozido em uma combinação de receita específica. Dentro das unidades de catering que oferecem o serviço tradicional de produção, a equipe de funcionários da cozinha e o equipamento usado não são empregados em sua melhor produtividade (a figura 1 demonstra o fluxograma desta produção). Isto é devido ao "pico" da produção alcançada antes da distribuição da refeição. Em muitos estabelecimentos tradicionais o uso de dispositivos elétricos e gás é muito grande: estes são gerados freqüentemente desde às 6 horas da manhã para um pequeno almoço, mas usados somente para a produção real do alimento por algumas horas (UNIVERSITY, 2004).

Figura 1 - Fluxograma de um sistema tradicional

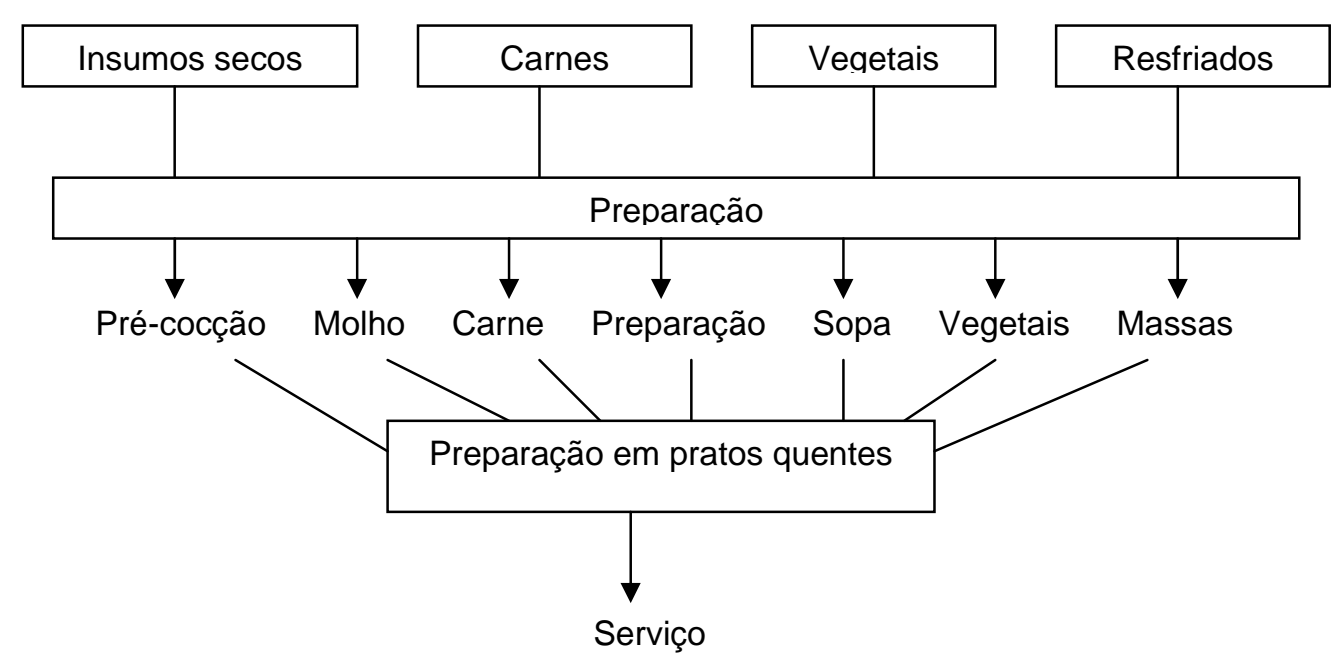

(fonte: UNIVERSITY, 2004) 


\subsubsection{Vida útil}

Ao contrário do processo tradicional, o alimento é cozido dentro da embalagem plástica, como demonstra a figura 2 e, em conseqüência disto, a qualidade do sabor será realçada, pois o sabor e o aroma se reterão na embalagem; a qualidade nutritiva também será realçada, perdendo menos vitamina e a vida útil (shelf-life) é prolongada. O produto Sous Vide cozido e armazenado sob ótimas circunstâncias (temperatura e embalagem), pode ter uma vida útil de 12 dias a 14 dias. Para o fornecedor é essencial que o equipamento que está sendo usado seja correto e assegure a qualidade do produto. Mas este por sua vez pode aumentar o custo do consumidor (este pode ser um fator que determine o por quê do Sous Vide ser usado principalmente em hotéis cinco estrelas, restaurantes caros, porque cada prato é embalado individualmente). Ele tem a vantagem, entretanto, de ter um armazenamento mais fácil e desde que a rotação estrita necessária dos produtos seja observada, reduz o problema da contaminaçãocruzada (UNIVERSITY, 2004). 
Figura 2 - Fluxograma de Produção Sous Vide

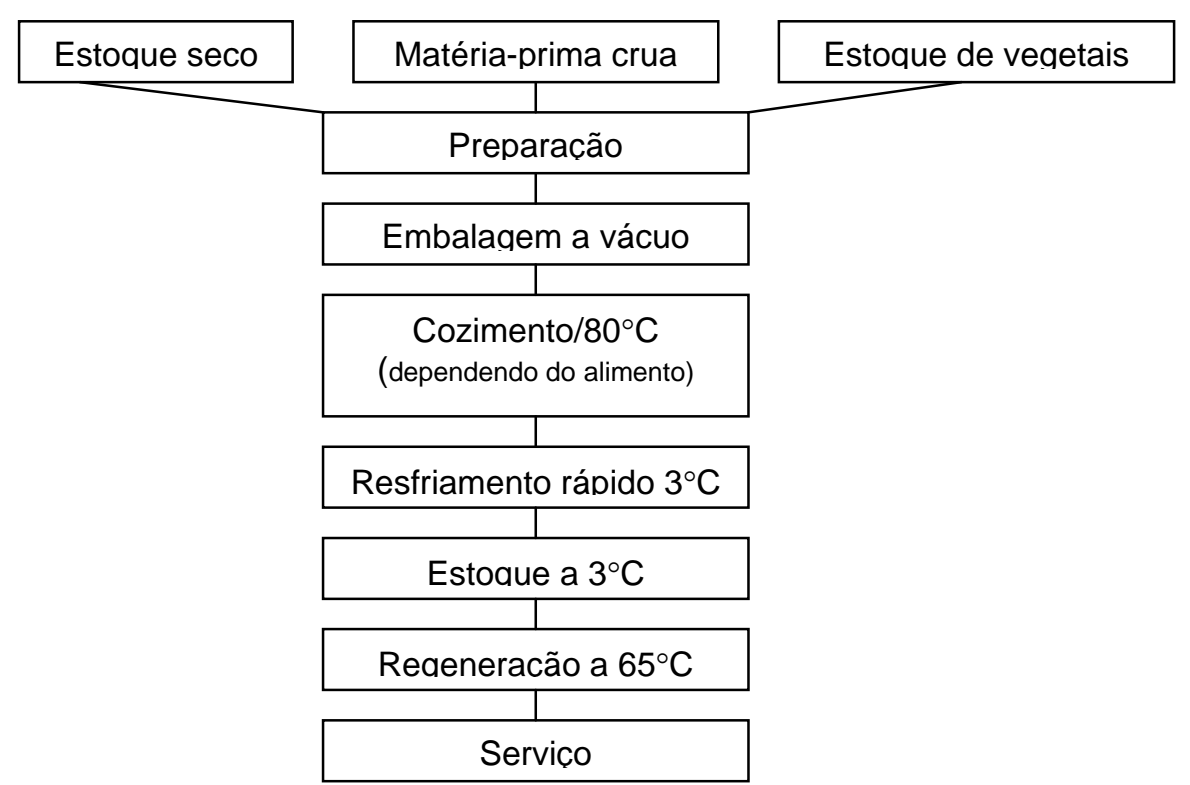

(fonte: UNIVERSITY, 2004)

\subsubsection{Sensorial}

Numerosas análises sensoriais, utilizando descritores pertinentes da qualidade, foram realizadas em pratos cozidos elaborados a vácuo com temperaturas entre $70^{\circ} \mathrm{C}$ e $100^{\circ} \mathrm{C}$, comparativamente com pratos idênticos oriundos do conjunto igualmente a vácuo com temperaturas ótimas de sua valorização. A diferenciação se faz sempre sobre o suculento/seco. Os efeitos de cozimento no suco ou no molho a alta temperatura não permitem, em nenhum caso, mascarar o aspecto seco da parte protéica do prato. Os produtos oriundos das bases culinárias são sempre mais 
suculentos e a aromatização mais homogênea num elemento e mais aparente entre os elementos que compõem o prato (CREA, 2000).

A colocação destes produtos na cozinha central e nas indústrias, seu uso em cozinha, são a fonte de um verdadeiro debate organizado em volta de três eixos:

- produção industrial ou artesanal em grande escala

- desqualificação ou nova qualificação do pessoal de cozinha

- segurança alimentar e validade das bases culinárias preparadas na temperatura correta em relação aos pratos cozidos pasteurizados.

\subsubsection{Microbiologia}

O comportamento dos patógenos Listeria monocytogenes e Yersinia enterolítica foi analisado por Mc MAHON (2003) com relação ao processo Sous Vide e as condições de armazenamento. Investigações iniciais examinaram a resistência térmica destes patógenos, usando temperaturas suaves, as quais imitam àquelas empregadas no sistema Sous Vide. Os resultados indicaram que o efeito do choque térmico induzido pelo sistema Sous Vide é fatal para os microrganismos, os quais não poderiam sobreviver aos tratamentos térmicos recomendados atualmente pela indústria do Sous Vide. Estudos subseqüentes examinaram o crescimento destes patógenos na carne cozida e embalada a vácuo, armazenada de $0^{\circ} \mathrm{C}$ a $10^{\circ} \mathrm{C}$. Estes estudos determinaram a influência da temperatura e do armazenamento na microflora destes patógenos. Os 
resultados destacaram a importância do armazenamento a temperaturas baixas para o prolongamento da vida de prateleira e melhorar a segurança de produtos Sous Vide.

No campo do risco patogênico, alguns estudos foram realizados nos Estados Unidos. Eles mostram que o conjunto de formas vegetativas das bactérias patogênicas é destruído entre $52^{\circ} \mathrm{C}$ e $53^{\circ} \mathrm{C}$, só resistindo os esporos dos diferentes Clostridium. Assim, parece que os riscos são os mesmos para um cozimento a $58^{\circ} \mathrm{C}$ e cozimentos variando entre $70^{\circ} \mathrm{C}$ e $100^{\circ} \mathrm{C}$. Em todos os casos, somente sobrevivem, em termo de bactérias patogênicas, os esporos que não devem ser colocados em condições favoráveis para a sua germinação. Isto justifica, em caso de necessidade, a exigência de uma refrigeração rápida no final do cozimento e a conservação dos produtos de $0^{\circ} \mathrm{C}$ a $3^{\circ} \mathrm{C}$ durante todo seu tempo de validade (CREA, 2000).

No campo da alteração, o risco é mais difícil de ser apreendido porque os estudos sobre este tema nunca foram publicados. De acordo com trabalhos realizados, as bactérias do gênero Pseudomonas, Brochotrix, Micrococos, Bacillus, Enterobactérias, as quais contribuem na alteração dos produtos, não são sistematicamente destruídas pelos cozimentos em temperaturas inferiores a $65^{\circ} \mathrm{C}$, pois seu crescimento precisa de um aporte de oxigênio, o que teoricamente não existe no produto cozido a vácuo (CREA, 2000).

O risco parece então diretamente ligado à qualidade do material de acondicionamento para o cozimento, que deve ser o mais possível uma alta barreira ao oxigênio. Nestas condições, o equilíbrio microbiológico entre as bactérias saprófitas 
evolui da mesma maneira no produto cozido e no caso dos produtos crus acondicionados a vácuo. A fase de latência dos lactobacilos é levemente maior e leva uns vinte dias devido ao estresse provocado pelo cozimento. Quando os produtos são conservados entre $0^{\circ} \mathrm{C}$ a $3^{\circ} \mathrm{C}$, os riscos de alteração são mínimos.

No entanto, é necessário tornar relativa esta análise dos riscos. De fato, um grande número de agentes sápidos ou de aromatização possuem propriedades bacteriostáticas, até mesmo bactericidas. Estas propriedades são ainda pouco conhecidas, mesmo que elas tenham contribuído para a salubridade das propriedades culinárias desde suas origens. A acidez trazida pelo uso do vinho tinto ou branco, os taninos do vinho tinto, o alho bravo do pot au feu (prato composto de carne de boi cozida com cenouras, alho bravo, nabos), o cravo nas carnes cozidas, o alho, o louro, o timo, fazem parte destes agentes de aromatização que permitiram a nossos antepassados, na época em que não existiam as câmeras frias, constatar e dizer que os cozidos eram melhores quando quentes.

Ainda hoje, faltam numerosos trabalhos de pesquisa a serem realizados para passar da simples medida e constatação destes fenômenos a seu domínio técnico e científico.

É muito bom constatar que a direção Geral da Alimentação no Ministério da Agricultura lança um apelo de ofertas para estudar ao mesmo tempo as bases teóricas e práticas do comportamento das bactérias patogênicas e das bactérias de alteração nos produtos agro-alimentares oriundos destas novas técnicas. Seria interessante 
prolongar estas pesquisas em direção ao comportamento das enzimas proteolíticas nos produtos cozidos a baixa temperatura, para confirmar e garantir seu verdadeiro tempo de validade. Qual centro de pesquisa não constatou que o peixe é melhor quando cozido completamente por volta de $56^{\circ} \mathrm{C}$, sua carne mais macia e perfeitamente nacarada? Mas esta qualidade organoléptica tem um tempo curto de validade à medida que este fraco cozimento não desnatura as enzimas proteolíticas internas: tal produto não se conservará muito mais tempo do que o produto cru equivalente, mesmo se a análise microbiológica se revelar satisfatória após 15 dias de conservação (CREA, 2000).

A qualidade de uma base culinária de conjunto preparada a vácuo e a baixa temperatura buscarão sempre o melhor compromisso entre sua qualidade organoléptica, sua validade, sua salubridade e seu custo econômico.

Devido ao produto ser cozido dentro de embalagem a vácuo, e permanecer nela até o consumidor, a possibilidade do produto ser recontaminado é zero, visto que não há manipulação direta do produto após o cozimento.

A manipulação de alimentos é um fato que merece muita atenção na indústria de alimentos. Apesar da evolução tecnológica das últimas décadas, quanto às técnicas de conservação e higiene dos alimentos, as doenças por eles transmitidas têm sido consideradas como um grave problema de saúde pública em escala mundial, onde os alimentos são reconhecidos como o principal vetor das enfermidades entéricas agudas (OLIVEIRA et al., 2003). 
Daí a vantagem do sistema de cozimento Sous Vide. Além de não existir manipulação após o cozimento, o choque térmico realizado durante o mesmo minimiza a flora bacteriana existente no alimento ou até corrige erros durante a produção do produto antes de ser cozido como, por exemplo, a má manipulação no alimento.

É certo que os referenciais atuais que dizem respeito à microbiologia alimentar não podem ser levados em conta pela maioria desta gama de temperatura, as quais se situam entre $56^{\circ} \mathrm{C}$ e $68^{\circ} \mathrm{C}$. O 'valor pasteurizador' de um cozimento se define hoje em relação à destruição de uma população de estreptococos fecais que começa, de maneira significativa, a partir de $65^{\circ} \mathrm{C}$ (GOUSSAULT, 1993).

Estudos importantes foram realizados pela Sociedade Científica de Higiene Alimentar com o concurso da Direção Geral da Alimentação no Ministério da Agricultura e a participação de um grupo de industriais interessados nestas técnicas, os quais estudaram os comportamentos das bactérias patogênicas e da flora saprófita. Semeações foram feitas nos produtos escolhidos para que se obtivesse uma grande variedade de suportes e um grande leque de tipos de cozimento: simples aumentos térmicos a $58^{\circ} \mathrm{C}, 62^{\circ} \mathrm{C}$ e $66^{\circ} \mathrm{C}$ várias horas antes da refrigeração. As bactérias patogênicas estudas por semeação e cozimento completo dos produtos foram as seguintes:

- Salmonella typhimurium

- Staphylococcus aureus

- Clostridium perfringens nas formas vegetativas e de esporos 
- Listeria innocua, que foi preferida a Listeria monocytogenes devido ao seu caráter não patogênico.

O comportamento da flora saprófita foi estudado pela medida da evolução das bactérias realmente presentes na superfície dos produtos e pela semeação das cepas referenciadas: Pseudomonas fragi, Brochothrix thermosphacta, Lactobacillus lake, Lactobacillus viridescens, Enterococcus faecalis. Estes ensaios foram realizados em meio tampão fosfato e extrato de carnes a pH 6,2.

Assim, no campo da salubridade dos produtos cozidos a vácuo na temperatura correta, é possível afirmar que as bactérias patogênicas presentes nos produtos sob formas vegetativas são destruídas num cozimento a $62^{\circ} \mathrm{C}$. Aliás, é possível definir para cada uma delas o valor de tempo de redução decimal e temperaturas permitindo controlar o cozimento utilizando um referencial de valor pasteurizador adaptado (GOUSSAULT, 1993).

A Listeria innocua, quando está presente nas matérias, constitui um excelente exemplo de eficiência do tratamento térmico. Os esporos do Clostridium perfringens não são destruídos por estes tratamentos térmicos. Eles são lesados à medida que o aumento térmico altera o sistema enzimático capaz de dar início à germinação. As técnicas analíticas clássicas nem sempre permitem enumerar estes esporos lesados. Eles podem, a qualquer momento, regenerar seu sistema enzimático que inicia a germinação sem que este fenômeno possa ser controlado. 
Os riscos ligados aos esporos do Clostridium perfringens são os mesmos entre os cozimentos a $58^{\circ} \mathrm{C}$ e $98^{\circ} \mathrm{C}$, e para controlá-los é preciso refrigerar rapidamente os produtos após cozimento e mantê-los entre $0^{\circ} \mathrm{C}$ e $3^{\circ} \mathrm{C}$ durante sua validade (GOUSSAULT, 1993).

Da mesma maneira, os ciclos de cozimento na temperatura correta permitem destruir, em parte ou na sua totalidade, os diferentes componentes da flora saprófita de acordo com a natureza do ciclo térmico.

O Brochothrix thermosphacta pode ser visto como exemplo do nível térmico do cozimento já que ele aparece como o mais sensível à temperatura. Quando da conservação destes produtos cozidos a $58^{\circ} \mathrm{C}$ e cozimento completo, a evolução da flora saprófita é idêntica a dos produtos crus equivalentes se o $B$. thermosphacta não tiver sido totalmente destruído, mas com um prolongamento significativo da fase de latência das bactérias láticas. Quando o B. thermosphacta é totalmente destruído, a flora saprófita não evolui se o material de acondicionamento é uma barreira ao oxigênio (GOUSSAULT, 1993). 


\section{CONCLUSÃO}

Esta pesquisa foi importante, no que diz respeito a abertura de um novo ramo na área de conservação de alimentos, visto que este sistema - Sous Vide - é, ainda, tão desconhecido na área científica.

Foram demonstradas as suas vantagens, com relação a aceitação, tanto para os consumidores diretos quanto para a indústria de alimentos, pela praticidade, gosto, aparência e sabor ressaltados e, principalmente, pela segurança disponibilizada nestes produtos submetidos a este tipo de cozimento.

Todo o problema da pesquisa é definir perfeitamente esta base culinária que representa, de alguma maneira, a interface entre o que pode ser industrializado numa receita e o que deve continuar de domínio artesanal do conjunto em cozinha. Este conceito interessa hoje aos industriais na proporção em que um grande número de bases culinárias é comum a numerosas receitas. É mais interessante para um ateliê preparar 12 bases que originarão 200 receitas do que preparar cada uma destas 200 receitas na cozinha central.

Com a oportunidade de conhecer com mais profundidade, este sistema é visível e perceptível, no que diz respeito ao paladar, sabor, beleza, harmonia e segurança do alimento que podem, sim, estar unidos. 
É interessante fazer uma análise dos riscos de salubridade dos produtos oriundos destes novos cozimentos. Do ponto de vista patogênico, os riscos são idênticos entre um produto cozido a vácuo na temperatura correta acima de $58^{\circ} \mathrm{C}$ e um prato cozido sob atmosfera modificada entre $70^{\circ} \mathrm{C}$ e $90^{\circ} \mathrm{C}$ : todas as formas vegetativas das bactérias patogênicas são destruídas, só permanecendo as formas dos esporos. Assim, para evitar a germinação e posterior desenvolvimento, os produtos devem ser refrigerados rapidamente ao fim do cozimento e mantidos de $0^{\circ} \mathrm{C}$ a $3^{\circ} \mathrm{C}$. Entretanto, um produto cozido na temperatura correta que, conserva uma parte de sua flora de alteração, será sem dúvida nenhuma mais frágil, mas muito mais seguro na conservação. De fato, no caso de rompimento na cadeia de frio ou de aumento de temperatura de conservação, primeiro ocorrerá uma alteração visível do produto antes que ele se torne potencialmente perigoso. Este não é o caso dos produtos pasteurizados que não contêm os demarcadores da alteração. 


\section{REFERÊNCIAS BIBLIOGRÁFICAS}

ARMSTRONG, Gillian A. Sensory quality / consumer acceptance of foods processed by the sous-vide system. University of Ulster Online. Disponível em: <http://www.science.ulst.ac.uk/Sensory_Analysis.htm>. Acesso em 07 de nov. 2003.

CREA, Centre de Recherche et DEstudes pour L'Alimentation. França, novembro de 2000.

GOUSSAULT, Bruno. Cuissons à Juste Température. Actualités Techniques et Industrielles. Paris, setembro de 1996.

GOUSSAULT, Bruno. Produits cuits sous vide et plats cuisines en atmosphere modifiée. Actualités Techniques et Industrielles, Paris, junho de 1993.

KOLVA. What is Sous-Vide?. Krankenhauskueche. Disponível em : <http://www.kolva.dk/eng/sousvide/sousvide01.htm>. Acesso em 07 de nov. 2003.

MC MAHON, Carol M.M.. Pathogen Control In Sous Vide Processing By Thermal Inactivation And Multiple Hurdle Tecnology. University of Ulster Online. Disponível em: <http://www.science.ulst.ac.uk/food/Sous_Vide_Processing.htm>. Acesso em 07 de nov. 2003. 
OLIVEIRA, Amanda de Morais; GONÇALVES, Mileide Oliveira; SHINOHARA, Neide Kazue Sakugawa; STAMFORD, Tânia Lúcia Montenegro. Manipuladores de Alimentos: Um Fator de Risco. Revista Higiene Alimentar, São Paulo, v. 17, n 114/115, novembro/dezembro de 2003.

TUDO, 10 em. Conservação dos Alimentos: Desinfeccção e Esterilização. Disponível em:

<http://www.10emtudo.com.br/demo/biologia/conservacao_dos_alimentos/index_1.html >. Acesso em 12 de nov. 2003.

UNIVERSITY, Sheffield Hallam. Food Production Methods. Disponível em: <http://www.shu.ac.uk/schools/ffm/teaching/jk/catdes/week05/week5.doc>. Acesso em 12 de jan. 2004. 